\title{
Race and Class in the Post-War World: The Southern African \\ Labour Congress
}

\author{
Duncan Money ${ }^{1}$
}

Text version of my article that was published in International Labor and Working-Class History, 94 (2018), pp. 133-55.

https://doi.org/10.1017/S014754791800011X

\section{Introduction}

Participants in the Southern Africa Labour Congress in 1943 regarded the gathering together of white trade unionists and labour MPs from across South Africa, Southern Rhodesia, Northern Rhodesia and Belgian Congo as a historic occasion. During three successive annual Congresses, delegates sought to secure their place in the post-war world and ensure that the white labour movement would have its say in what this world would look like. Collectively, they developed, articulated and then disseminated internationally a racialized understanding of class intended to be acceptable for the post-war period. Although white workers comprised only a small proportion of the working-class in the region, white labour representatives considered white workers to be the legitimate working-class, an assumption based on hierarchical notions of work that were not peculiar to them. Historically, some types of work have been considered more valuable than others, and the labour of some has been judged as more valuable than labour performed by others. In Southern Africa, the white labour movement regarded skilled work performed by white men as the defining characteristic of who was, and who was not, working-class, a definition that had some circularity as work 
performed by white men was often defined in law as skilled. On this basis, organisations of the white labour movement were authentic representatives of the working-class.

The Congress has since been forgotten and, to my knowledge, has not attracted a single mention in the considerable secondary literature on labour in the region. Yet its participants, who were at the centre of the white labour movements, considered the meetings to be of major significance. Two related reasons help explain why the Congress has been overlooked. The first is the shape of archives, which tend to adhere to the structure of the nation-state and into which transnational organisations do not easily fit. When the Congress ceased to exist in 1946 there was no one national organisation which could lay claim to its documents. In this sense, the transnational character of the organisation was a weakness as well as a strength. The Congress had no independent existence outside of the national-level organisations which comprised it. When they disintegrated in 1946, so did the Congress. No single collection of documents relating to the Congress has survived and accounts of its proceedings are scattered across the archives of its constituent organisations, personal papers of prominent participants and contemporary newspaper reports. Correspondence, minutes and reports derived from these form the basis of this article.

The second reason also relates to the transnational status of the Congress: much of the vast and detailed body of work on labour history in the region have been national labour histories. ${ }^{2}$ As Philip Bonner, Jonathan Hyslop and Lucien van der Walt note in the case of South Africa, "activist and revisionist scholars tended to take South Africa as the unit of analysis, and to examine labour history as South African labour history."3 This is part of what Keith Breckenridge regarded as the implicit view in South African historiography "that South African history is sui generis, completely distinct from any 
other society, and disconnected by its history from both its neighbours and distant colour peers." ${ }^{4}$ Van der Walt developed the argument further and noted that the same is true for other parts of the region, where a national labour history is "presented as taking place within a distinctively national context where organisational and political boundaries correspond with the administrative borders of the state."

This article will explore an integrated regional labour history, one where representatives of the white labour movement sought to organise across borders to strengthen their own movements, tackle common problems and reach out to the wider labour movement. In doing so, this article will utilise the insights of one innovative approach to understanding South African labour history in a transnational context: the concept of 'white labourism'. This was an ideology where radical critiques of economic exploitation were intricately linked with the establishment of racial hierarchies in the workplace and white domination. ${ }^{6}$ As will be seen, the politics of the Southern Africa Labour Congress represented a similar combination, though advocates of white labour were sensitive to the shifting international context and avoided crude racism or making demands for inclusion on the basis of whiteness. Principles of self-determination and anti-racism that ran counter to this racially exclusive vision came to the fore during the Second World War and made it all the more important for the white labour movement that they secure a central role for themselves in the post-war world.

This article also intends to offer a historical comparison to contemporary discussions about class and the rise of right-wing populism. In these discussions, the term 'working-class' is commonly used to refer to manual jobs predominately performed by white men - Virginia coal miners, factory workers in Nord-Pas de Calais, or white vandriving builders from Essex - even though the numbers employed by these industries in developed economies have shrunk substantially in the last 40 years. Conversely, 
retail workers or care-workers, whose numbers have swelled over the same period, are discussed in terms of class much less frequently. ${ }^{7}$ In essence, the language and popular understanding of class has become decoupled from the structure of the real economy. In Southern Africa during the 1940s, there was a concerted effort to do the same: to present white male workers as the natural working-class in the region, even though the large majority of wage work was performed by African workers. This goal motivated, and found its clear expression in, the formation of the Southern Africa Labour Congress.

Revival of the white labour movement and the formation of the Congress

White labour organisations from across Southern Africa greeted the call for the formation of the Congress in late 1942 with enthusiasm. Support for the idea of holding the Congress was rooted in three developments: the revival of the white labour movement, a growing sense that an Allied victory in the war was assured, and the increased assertiveness of African workers. The first of these was critical. Following an upsurge of militancy after the First World War, heavy defeats were inflicted on the white labour movement in South Africa and Southern Rhodesia and it took many years for the movements to recover. ${ }^{8}$ By the early 1940s, however, white labour representatives had grounds for optimism, as the size, importance and unity of their movement grew. In South Africa, membership of registered trade unions rose dramatically from 89,000 in 1934 to over 250,000 by 1942 , a large majority of whom were white workers. ${ }^{9}$ The South African Trades and Labour Council (SATLC), a national trade union federation based in Johannesburg, increased its number of affiliates, notably attracting the re-affiliation of the South African Mine Workers' Union , one of the largest white unions in the country, in 1940 and merging with the Cape Federation of Labour Unions, a rival national body, in $1945 .{ }^{10}$ 
Unlike in Britain, trade unions in Southern Africa were not organisationally linked to national labour parties, though prominent individual trade unionists were often members. This changed in the early 1940 s as the SATLC and South African Labour Party (SALP) sought closer co-operation. These efforts reached fruition in April 1942 when the annual congress of the SATLC voted overwhelmingly "to bring about the closest collaboration with the political wing of the labour movement, namely, the South African Labour Party."11 Notably, the proposer of this motion, Ben Weinbren, was subsequently a delegate at the first Southern Africa Labour Congress. That same year, five more white trade unions affiliated directly to the SALP. ${ }^{12}$ Contemporaries regarded the Congress as the outgrowth of growing unity at a national level. Reflecting on the third Congress, Fred Tyler, British-born General Secretary of the Amalgamated Society of Woodcutters, noted that the SATLC's involvement "was the natural outcome of a resolution... that the industrial labour wing collaborate with the political labour wing."13

A similar process of growth and consolidation was underway in Southern Rhodesia. In 1938, white unions on different mines merged to form a single white mineworkers' union: the Associated Mine Workers' Union. ${ }^{14}$ The union quickly established itself across the colony and reached an agreement with the Chamber of Mines in 1940 to create bargaining and conciliation machinery for the whole industry. ${ }^{15}$ The establishment of the mineworkers' union was followed by the creation of an umbrella organisation for the colony's white trade unions in 1939: the Southern Rhodesia Trades and Labour Council, which sought to establish close links with the SATLC. ${ }^{16}$ At the same time, the fortunes of the Rhodesia Labour Party (RLP) revived. Electoral support for the RLP had grown steadily during the 1930s and in the April 1939 
elections the party emerged as the official opposition, winning $33 \%$ of the vote and seven of the thirty seats in parliament. ${ }^{17}$

Success for the newly-formed Northern Rhodesia Labour Party (NRLP) was even more dramatic. The whites-only party was only formed in February 1941 yet all five labour candidates who stood in the 1941 legislative council elections won their seats. ${ }^{18}$ The same year, the colony's largest white union, the Northern Rhodesia Mine Workers' Union (NRMWU) secured a closed shop and an industrial colour bar on the mines through strike action. NRMWU members were also closely involved in efforts to form a white mineworkers' union in Belgian Congo during 1941 as the copper mines in Katanga Province were located directly across the border from the Northern Rhodesian Copperbelt. Most white mineworkers in Katanga quickly joined the new union, Association des Agents de l'Union Minière et Filiales, and unions for white railway workers and civil servants soon followed. ${ }^{19}$ The colonial authorities and employers in Belgian Congo made sustained efforts to crush the nascent white labour movement during 1942 and so white workers in the colony sought external support to bolster their position. ${ }^{20}$

The onset of the Second World War provided another boost to labour parties in all three territories as they were granted positions of political power. Following the example of Britain, the South African and Southern Rhodesian Governments formed national governments and invited labour MPs to join the Cabinet. Walter Madeley, a British-born engineer who had sat as an SALP MP since 1910, joined the South African government as Minister of Labour while in Southern Rhodesia RLP leader Harry Davies was appointed Minister of Internal Affairs. ${ }^{21}$ In Northern Rhodesia, where the Legislative Council remained subordinate to the Governor, NRLP leader Roy Welensky was appointed to the territory's Executive Council in $1940 .{ }^{22}$ 
Davies accepted his ministerial position without consulting his party. His subsequent refusal as well as that of Jack Keller, British-born General Secretary of the Rhodesia Railway Workers' Union (RRWU) who revelled in his nickname 'the Lenin of Rhodesia', also appointed a minister, to resign from government triggered a split in the party. Both men resigned from the RLP and formed a new party, confusingly known as The Labour Party. ${ }^{23}$ Relations between the two parties were extremely acrimonious yet such was the appeal of the Southern Africa Labour Congress that both sides attended.

Consolidation of the white labour movement cannot be disentangled from the growing demands of African workers in this period to be recognised as such. African workers and trade unionists had long made efforts to puncture the self-image of the white labour movement as the authentic representatives of the working-class. This was occasionally expressed in terms of disbelief at the effrontery of white trade unionists in claiming the mantle of 'working-class' since African workers performed almost all manual work. "We are the workers. We make houses and lay roads. Any reasonable person can see that we are the workers," argued Masotsha Ndlovu, Secretary General of the Industrial and Commercial Workers' Union in Southern Rhodesia, in a 1929 speech attacking the RLP, "[yet RLP MPs] spoke for the white people as labour leaders." 24

Under the legislation governing industrial relations in both South Africa and Southern Rhodesia, the Industrial Conciliation Acts, Africans were excluded from the definition of 'employee' and African unions were excluded from industrial bargaining machinery. Furthermore, this legislation had been supported, or, in the case of South Africa, introduced, by the white labour movement, which mostly continued to support the colour bar that this legislation formalised. Although the SATLC supported a policy of 
non-racialism and full legal rights for African workers from 1930, it had taken little action in pursuit of these aims. ${ }^{25}$ Other components of the white labour movement made their positions clear. The RLP's 1938 'Statement of Policy' stipulated that “in the white areas... the native will be confined largely to the performance of the unskilled work." ${ }^{26}$ Similarly, the SALP confirmed in 1943 that it recognised "the existence of and necessity for a colour bar" and did not campaign for its immediate removal. ${ }^{27}$

Challenges by African workers intensified during the 1940s. In November 1941, a conference of African trade unionists established the Council of Non-European Trade Unions (CNETU) from existing unions. One of the main demands that emerged from this conference was recognition of African workers as employees under the Industrial Conciliation Act. ${ }^{28}$ The white labour movement was well-aware of these demands. In June 1942, Madeley had been personally informed by Dr Alfred Xuma, president of the African National Congress, that African workers would not accept "anything short of recognition under the Industrial Conciliation Act." ${ }^{29}$ Madeley would then have heard this same demand reiterated when he opened the CNETU annual conference in October 1942. Legislative industrial colour bars did not exist in Belgian Congo and Northern Rhodesia but there was still a clear racial hierarchy in the workplace: African workers performed the toughest jobs for the lowest pay, though Congolese workers undertook skilled work restricted to whites elsewhere in the region. There were major strikes by African mineworkers on both sides of the border in 1940 and 1941, which were violently suppressed. ${ }^{30}$

Conceptions of class and the organisation of the Congress

The initiative for the Congress came from Roy Welensky, a Southern Rhodesian-born trade unionist who rose to prominence representing white railway workers and who 
subsequently became a prominent settler politician. Welensky wrote to Colin Henderson, SALP General Secretary, in September 1942 to suggest a meeting of all labour parties in the region. Henderson was enthusiastic about the idea and promised to place it before the party's National Executive Committee at their next meeting. ${ }^{31}$ The committee was equally enthusiastic and soon began distributing invitations to white labour organisations across the region. Welensky's suggestion was a timely one. While arrangements for the Congress were underway, the tide of the war turned against the Axis powers and confidence in an Allied victory grew. In May 1943, German and Italian forces surrendered in Tunisia, bringing to an end the campaign in which most white troops from Southern Africa had fought. ${ }^{32}$ Now was the time to plan the post-war world.

The suggestion was also timely as the entry of the Soviet Union into the war in June 1941 had healed a breach in the white labour movement. Communists, who had initially opposed the war, now swung whole-heartedly behind the war effort and official suspicion about their activities dimmed. For a brief period, the Soviet Union enjoyed unprecedented prestige among whites across the region and, partly by dint of association, there was a revival of support for the Communist Party of South Africa, the only communist party in the region. ${ }^{33}$ Communist trade unionists were active participants in the Congresses and attempted, with occasional success, to push delegates leftwards.

Members of the white labour movement were not the only ones who sensed that a new era of possibilities was opening up in the 1940s. Many other sections of South African society recognised that the onset of the Second World War "shook up established certainties" and this "proved a powerful stimulus to new thought," as the edited volume by Saul Dubow and Alan Jeeves argues. ${ }^{34}$ The discussion in that 
volume is limited to South Africa, however, and the competing vision of the future advanced by the South African labour movement was not conceptualised and sought by them alone but in conjunction with white labour activists from across the region.

Participation in the Congress was deliberately restricted to racially exclusive organisations or trade unions which were formally multi-racial but in which Africans, Indians or Coloured workers played at best a nominal role. Invitations were sent out from Johannesburg far and wide to small white trade unions - the largest white trade unions in Northern and Southern Rhodesia, the NRMWU and RRWU, had only 2,052 and 1,678 members respectively in 1941 - while larger African trade unions on the Rand were ignored. ${ }^{35}$ This was based on a highly racialized and gendered understanding of class. Productive skilled work was, it was thought, work which was carried out by white men, and almost all white men in South Africa, Northern and Southern Rhodesia worked. 87\% of white men over the age of 15 in South Africa were economically active in 1939, while in Southern Rhodesia the figure was around $84 \%$ in 1942, and in Northern Rhodesia $86 \%$ of white men were economically active in 1946. ${ }^{36}$ African workers were considered unskilled labourers, regardless of the work they actually performed, whose role was to assist white workers and who properly belonged in rural areas. Where white female workers performed the same jobs as white male workers, such as in the South African metal industry during the Second World War, white trade unions considered them 'temporary workers', their employment a necessary wartime expediency, and deserving of lower pay. ${ }^{37}$

Welensky's proposal was likely motivated by a perception that the position and presence of the white population in Northern Rhodesia was particularly precarious. The territory's white population was small and virtually non-existent outside the main industrial centres and the powers of the Legislative Council they elected were limited. 
Real political power lay with the Colonial Office and there was little possibility that the British Government would accede to vociferous demands by white settlers to amalgamate Northern and Southern Rhodesia as a self-governing colony. ${ }^{38}$ White domination over the territory could not be assured by their own efforts. Urgency was injected into demands for amalgamation by the publication of a short pamphlet on colonial policy by the British Labour Party, which circulated widely among the white labour movement in Southern Africa. This pamphlet pledged that a future Labour government would uphold the principle that African interests were considered paramount in Northern Rhodesia and ruled out further constitutional change for the colony. ${ }^{39}$

White labour advocates across Southern Africa possessed a conviction that criticisms emanating from the British Labour Party resulted from misunderstanding or lack of knowledge and could be rectified within the labour movement. This conviction stemmed from the personal experience in, or close ties with, the labour movement in Britain and elsewhere in the British Empire of many participants in the Southern Africa Labour Congress. They considered the labour movement in Britain to be their movement. White labour publications from across the region regularly reprinted articles from British Labour MPs and trade unionists alongside news and analysis from the labour movements in Australia, Canada, and New Zealand. White labour organisations shared a common language (English) and a sense of a common history as "the initial organisation and growth of South African trade unions... can be attributed to the efforts of immigrants, largely from Britain and Australia," and the same was true in Northern and Southern Rhodesia. ${ }^{40}$ Belgian Congo is seemingly the outlier here as the white workforce there overwhelmingly originated from Belgium but, as mentioned above, white mineworkers from Northern Rhodesia were involved in the formation of 
trade unions there. Information about Belgian Congo's white workforce, their organisations and struggles was largely transmitted to the white labour movement elsewhere by NRMWU members. ${ }^{41}$

Yet the largely English-speaking male leadership of the white labour movement did not even reflect the structure and attitudes of the white working-class in the region, let alone the working-class as a whole. In South Africa, growing numbers of Afrikaners had left the land during the interwar years and joined the ranks of the urban workingclass. Many of these Afrikaner workers opposed South African involvement in the war. Afrikaner workers, however, tended to be clustered into the unskilled and semi-skilled tiers of the white workforce and were therefore mostly excluded from craft unions. ${ }^{42}$ There were trade unions with an overwhelmingly Afrikaner membership, notably die Spoorbond, the South African Mine Workers' Union, and the Garment Workers' Union (GWU), but these played no part in the Southern Africa Labour Congress.

English-speakers' dominance over the white labour movement had not been uncontested. From the mid-1930s, figures associated with the Afrikaner Broederbond, a shadowy organisation devoted to the advancement of Afrikaner nationalism, had made a determined effort to take control of existing unions or form separate unions under their control. These efforts met with dismal failure before the late 1940s, with the exception of die Spoorbond. ${ }^{43}$ This was a union of white railway workers founded in 1934 and it grew rapidly, reaching 29,000 members by 1942, though it aroused the ire of craft unions which successfully restricted the union to representing only the lowest grades of white workers. ${ }^{44}$ The craft unions on the railways were affiliated to the SATLC and it is likely that die Spoorbond leaders were never even invited to attend the Congress. 
The South African Mine Workers' Union was established by English-speaking white miners and they continued to dominate the union's leadership even though by 1936 around $90 \%$ of its 12,000 members were Afrikaners. The war intensified a vicious struggle for control of the union between the existing leadership and Afrikaner nationalists, a struggle involving numerous court cases, suspension of internal democracy, government enquiries into corruption, unofficial strikes, attempted assassinations, and the murder of the union's general secretary.$^{45}$ Immersion in this power struggle likely limited the active involvement of the union's leadership in the wider white labour movement, with the exception of H.J. Cilliers, who had been the union's vice-president before being elected an SALP MP in 1943 and was a delegate at all three Congresses. ${ }^{46}$

Similarly, although founded by English-speaking male tailors, by 1938 the bulk of the GWU's 7,000 members were Afrikaner women, as were almost all major officer bearers in the union. Importantly, the GWU also organised African and coloured workers in the garment industry. However, the GWU's political stance was significantly at odds with the rest of the white labour movement. Solly Sachs, the union's firebrand general secretary, opposed the war and argued that the labour movement should adopt an anti-imperial, republican stance that would encompass Afrikaner national aspirations. ${ }^{47}$ These political positions alone would have been enough to make the GWU an unlikely presence at the resolutely pro-war Congress but this was compounded by the GWU's decision, taken shortly before the first Congress, to launch an Independent Labour Party and issue a fierce denunciation of the SALP. ${ }^{48}$

The First Congress: Johannesburg, July 1943 
The first Congress saw a gathering of eight labour MPs and twenty-eight delegates representing most white labour organisations of significance in the region: the SALP, both labour parties in Southern Rhodesia, NRLP, SATLC as well as its local committees in Johannesburg, Pretoria and Bloemfontein, Cape Federation of Labour Unions, Southern Rhodesia Trades and Labour Council, Rhodesia Railway Workers' Union, Northern Rhodesia Mine Workers' Union, Fédération des Associations Syndicale du Katanga, and Union Generale des Associations Professionelles Congolaises.$^{49}$ At least two Communist Party members attended as SATLC delegates as well. Delegates from Southern Rhodesia's white mineworkers' union were unable to attend due to a protracted dispute following the sacking of L.T. Smith from Shabanie Mine, where he had been employed as an electrician, after he was elected Labour MP, but the union's journal carried a lengthy report of the proceedings. ${ }^{50}$ "This was," declared 'Forward', a left-wing newspaper aligned with the SALP, "a truly representative assembly of Labour and Trade Union representatives from the Union of South Africa, Southern Rhodesia, Northern Rhodesia, and the Belgian Congo." ${ }^{51}$

Delegates had an ambitious agenda for the two-day Congress. Walter Madeley opened the proceedings by declaring that "I am one of those who believes that it is absolutely inevitable that Labour will be ruling the world and that being so, we must prepare ourselves that we may be able to rule the world." With that end in mind, the fundamental principle for the conference to work toward was to "abolish the profitmaking system" and establish socialism. ${ }^{52}$ SALP delegates in particular could enter the Congress with confidence and purpose. The 1943 general election, held immediately prior to the Congress, had seen the number of SALP MPs increase from four to nine and the party had won all six mining constituencies on the Rand, mostly with large majorities. ${ }^{53}$ 
Much debate at the Congress focused on identifying and resolving common problems faced by the white labour movement in each territory. Two considerations dominated these discussions: the establishment of a better system of social security to avoid a repeat of the economic slump that occurred after the First World War, which many delegates had personally experienced, and what Harry Davies introduced as "the problem common to all... the racial question." Demographics featured in almost every contribution, focusing on the fact that Africans vastly outnumbered whites in each territory. Nevertheless, there was a keen awareness of the changing international context, and the Atlantic Charter issued by the Allied powers during 1941 was discussed. Efforts were made to portray the racialized division of labour as normal and several delegates compared the situation with the Soviet Union, where it was argued that equality had not been achieved among different ethnic groups. ${ }^{54}$

Two seemingly incongruous resolutions were passed in response to these debates. The first affirmed "that Socialism offers the only possible solution to the securing of Social Reconstruction" while the second called for "a greater flow of selected productive immigration after the war to the colonies" to assist post-war reconstruction. There was some debate about specifically calling for greater European immigration, but this was thought unnecessary as 'productive immigrants' was considered synonymous with 'European immigrants'. Ben Weinbren, an SALP member and former communist, spoke against the inclusion of 'European' but argued that: "We can do with a few more million people in South Africa, preferably British workers... I am in favour of a flow of immigration with a preference for British working-class stock." ${ }^{55}$

The link between these two resolutions was the shared assumption among delegates that more white workers were required for post-war development and prosperity as they were the ones who performed real, productive work. In this way, an increased 
white settler population would "serve the best interests" of the African population, who were deemed incapable of improvement through their own efforts. ${ }^{56}$ This formed what Josiah Brownell termed a "fundamental tenet of white settler ideology": that white settlers were necessary to bring about dynamic change "on largely static indigenous populations. ${ }^{" 57}$ Some speakers at the Congress directly attacked the idea that Africans were workers in any meaningful sense compared to white workers. Jimmy Briggs SALP chairman and a trade unionist with personal experience of the labour movement in Britain, Australia, Canada and the United States - drew on his experience as a bricklayer to claim "Many [Africans] who work in this country perform their work in the most inefficient manner possible. Their labour is of little real value." Some delegates did denounce racial discrimination, notably Isaac Wolfson, the South African-born Communist Party treasurer and leader of the Tailoring Workers' Union. However, Wolfson also specifically warned Congress about the danger of African workers undercutting whites by undertaking skilled work, noting "What can happen in Belgian Congo today can happen in South Africa tomorrow." 58

The other major task of the Congress was to successfully present themselves internationally as the legitimate representatives of the working-class in Southern Africa and secure agreement for their vision of a post-war world. Leading Rhodesia Railway Workers' Union members Roy Welensky and Tommy Grey, who had been born in Britain and emigrated to Southern Rhodesia as a young man, suggested inviting a delegation from the British Labour Party to Southern Africa so they could understand the situation in the region and thereby be persuaded that the politics of the white labour movement were acceptable and suitable. It was necessary to clear up misunderstandings within the labour movement as: 
Labour must speak with one united voice at the Peace Conference; in order to achieve unity on all outstanding issues, e.g. colonial policy, it is felt that immediate steps should be taken for the calling of an International Conference of Labour Parties.

Delegates closed the Congress with a rendition of 'The Red Flag', significant not only because of the choice of song but also because the delegates all knew the words. ${ }^{59}$

There was consensus that the Congress had been highly successful. Delegates therefore sought to repeat the Congress as an annual event and establish a permanent organisation with a constitution, executive and standing committee that would meet regularly between the annual Congresses. ${ }^{60}$ One immediate aim of the executive was to strengthen links between organisations across the region and facilitate the flow of information, so it was with this in mind that Duncan Burnside, an SALP MP, was sent on a speaking tour of Northern Rhodesia in September 1943.

Burnside, the SALP reported, "will visit all the larger centres, and will address workers on the mines... to stimulate greater interest in the principles of the Labour Party."61 This, of course, meant that Burnside addressed crowds of white railway workers and mineworkers, to whom he stressed the necessities of amalgamating Britain's colonies in the region to remove "the incubus of Colonial Office domination," and emulating the progressive social security policies of the New Zealand Labour Party. ${ }^{62}$ Developing links were reciprocal. The following month, NRMWU General Secretary and NRLP MP Marthinus Visagie, who was from South Africa and had previously worked on the Rand, visited Johannesburg and was given a fact-finding tour of the city so the NRLP could emulate SALP policy in Northern Rhodesia. ${ }^{63}$ It was originally proposed that Burnside would visit Northern Rhodesia and Belgian Congo, though the second leg of 
this trip never happened. Meanwhile, white workers in Congo were attempting to duplicate the organisation of the white labour movement elsewhere in the region, with white unions in Katanga forming an umbrella body, the Fédération des Associations Syndicales du Katanga, and discussing using this as a basis to form a labour party. ${ }^{64}$

\section{The Second Congress: Bulawayo, July 1944}

Bulawayo, in Southern Rhodesia, was an obvious choice to host the second Southern Africa Labour Congress. The city "was the stronghold of white trade unionism" and the birthplace of the RLP. ${ }^{65}$ By 1944 , the colony's white labour movement was also in a better position to organise the Congress. In October 1943, Davies and Keller were sacked from the government and, along with pressure from Rhodesia Railway Workers' Union branches, this paved the way for reunification of the labour party. The party was reformed as the Southern Rhodesia Labour Party (SRLP) in January $1944 .{ }^{66}$ It was a measure of wartime radicalisation that the new constitution of the reunified SRLP quoted the British Labour Party's Clause IV - which called for the common ownership of the means of production, distribution and exchange - as its principal policy clause.$^{67}$ Moreover, the colony's Trades and Labour Council used the occasion of the Congress to announce it was now considering supporting the SRLP. ${ }^{68}$

By July 1944 , it was clearly only a matter of time before the end of the war, bringing greater urgency to post-war planning. Colin Legum, a South African journalist who served as Congress secretary and as an SALP city councillor and who later became an anti-apartheid activist, wrote to all constituent organisations to point out that the next Congress would occur only a few months before the Dominion Labour Congress, which would bring together the labour movement from across the British Empire, so: 
it is of the utmost importance that a common policy should be formulated by the various labour organisation in Southern Africa, so that our views on the postwar problems shall be unanimous. This is particularly important in view of the differences of opinion which exist between the Southern Africa Labour Movement and the British Labour Party over Colonial Policy. ${ }^{69}$

The Southern Africa Labour Congress was part of a broader process of the strengthening and deepening of ties within the international labour movement. In mid1942, the British Trade Union Congress began preparations for a conference of trade unions from the Dominions and invited delegates from South Africa. Delegates exchanged information on trade union organisation, wages, working conditions, plans for post-war reconstruction and resolved "that closer contact should be established between the British Trade Union Movement and the respective Dominion Movements." 70

The 1944 Dominion Labour Conference, however, was thought to be more important. The 1943 conference had been relatively poorly attended as Australian delegates could not attend and the New Zealand delegate was killed en-route to London when his ship was torpedoed. Moreover, the 1944 conference was being organised for labour parties from the Dominions, rather than trade unions, and would address plans for post-war reconstruction more directly. It was therefore crucial for representatives from Southern Africa to attend. Although the British Labour Party had rebuffed the invitation in 1943 to send a delegation to Southern Africa, Congress delegates were not unduly disheartened. If the British Labour Party would not come to them, then they would go to it. 
At the second Congress, a clearer picture emerged of what the white labour movement sought in the post-war world and it was one where white domination over the region would be secured with the agreement of the international labour movement. Again, ideas of white domination were mixed in with radical critiques of the existing order. Congress delegates reaffirmed their support for socialism and pledged to complete "the task of ensuring that the promise of a better world after this war will be translated into reality." The "minimum criteria of economic justice" was "a comprehensive scheme of social security... for all sections of the population" and delegates vowed to impose as much taxation as necessary on "excessive wealth... until the results aimed at were achieved." 71 This vision of a 'better post-war world' would also involve a strengthening of white political power over the region:

This conference agrees that the time has come for a regrouping of territories in Africa on the basis of economic and social unity which will promote the interests of both the civilised and indigenous populations.

Radical arguments were deployed to support this proposal. C. Onclynx, a Belgian mineworker, argued "that the boundaries in Africa had been set up by capitalists. The workers of the Congo recognised no boundaries." Similarly, Duncan Burnside saw this regrouping as a blow to "the vested interests of Imperial masters and their local exploiters" as well as the first step to unification with South Africa, a logical step as the "three territories were all British territories." Jim Purvis, an Australian mineworker and Northern Rhodesian delegate, perhaps with the changing international context in mind, "believed that this was the last chance the white races were going to get." ${ }^{2}$ The Congress was not out of step with wider opinion in settler society. Proposed territorial mergers corresponded closely to the ideas of South African Prime Minister Jan Smuts who believed in enlarging South Africa to encompass several neighbouring colonies 
and had advocated this in a speech to the British House of Commons in $1943 .^{73}$ Discussions on amalgamating Northern and Southern Rhodesia at the Congress also prefigured the creation of the settler-dominated Central African Federation in 1953, and helped popularise the idea by bringing whites from across the region together and stressing their common interests.

Sections of the labour movement elsewhere in the world had to be convinced that this vision of the post-war world was legitimate and the Congress regarded one of its main tasks to be drafting "a practical colonial policy in so far as Southern Africa is concerned" for submission to the upcoming Dominion Labour Conference. ${ }^{74}$ Delegates clearly had great faith in their own powers of persuasion as another aspect of this colonial policy was "that native development be fully encouraged within the native reserves," effectively anticipating what would become a cornerstone of apartheid policy in South Africa. ${ }^{75}$

The next step was to ensure that sufficient delegates attended the Dominion Labour Conference to make the arguments. Rhodesian delegates had not been invited Southern Rhodesia was a self-governing colony but not a Dominion - and Donald Macintyre, a British-born SRLP MP, suggested approaching other labour parties around the British Empire to secure their support for the inclusion of Rhodesian delegates. ${ }^{76}$ This approach was partially successful as Canada's Co-operative Commonwealth Federation responded positively, but such entreaties, and those of the SALP, were rebuffed by the British Labour Party. ${ }^{77}$ Instead, the SALP pledged to "put forward the views of the Constituent Bodies of the Southern Africa Labour Movement" and requested other organisations send them points to be raised. ${ }^{78}$ 
South Africa's three delegates encountered a mixed reception at the Dominion Labour Conference in September 1944. Explanations from the South African delegates regarding their preferred colonial policy produced a restatement of British Labour Party policy as outlined in the 1943 pamphlet from Arthur Creech Jones, a Labour MP with a close interest in African affairs. Other labour parties present made no explicit criticism of the South African delegation but essentially the ideas of the Southern Africa Labour Congress were rebuffed. While the manifesto issued by the conference supported the formation of regional organisations, it also stated that the interests of Africans, not white settlers, should be paramount in Britain's colonial possessions. ${ }^{79} \mathrm{It}$ is worth noting that, in other ways, the SALP delegates were more radical than others present at the conference. For instance, they had unsuccessfully sought to include a paragraph in the conference manifesto blaming "the Tories and capitalist economics for the outbreak of war." 80

\section{The Third Congress: Johannesburg, August 1945}

The proposed locations of the three Congresses provide an insight into the mental geographies of the participants. Each was scheduled to take place amongst the highest concentration of white workers in each territory: first Johannesburg, then Bulawayo, and in 1945 Nkana, the largest town on the Northern Rhodesia Copperbelt. However, plans to hold the Congress on the Copperbelt were frustrated by the lack of preparation by Northern Rhodesian organisations and the Congress reverted to Johannesburg. ${ }^{81}$

Although thirty-one delegates gathered for the third Congress, regional participation was diminished. No delegates from Belgian Congo or Northern Rhodesia were present. White unions in Belgian Congo had organised their own national conference 
on the same day, while Northern Rhodesia's delegate, Hedley Priest, NRLP MP for Livingstone, simply didn't turn up. No Northern Rhodesian white trade unionists attended either. ${ }^{82}$ The second Congress had taken place during a wave of wildcat strikes by white mineworkers on the Copperbelt but solidarity from the Congress amounted to a suggestion that a delegate travel to the Copperbelt to obtain more information. ${ }^{83}$ Instead, assistance was sought, and obtained, from British trade unions. The Congress was of little use to striking workers.

Participation was further diminished by the renewed rift in Southern Rhodesia. In September 1944, the SRLP split along the same lines as previously. On this occasion, however, the disagreement was over the party's small African membership who were grouped in a single branch in Salisbury. A majority on the National Executive Committee supported the African branch - though they envisaged it as remaining in a subordinate role and developing "under European help and guidance" - but Davies, Keller, and their supporters in the railway workers' union and the mineworkers' union refused to countenance this. ${ }^{84}$ They formed another new party which became known as the Labour Party of Southern Rhodesia. This new party endorsed a policy of "the socialization of the means of production and distribution" and a membership criteria prohibiting any "member of the aboriginal tribes or races of Africa, or any person having the blood of any of the aboriginal tribes of races of Africa" from being admitted as a member. ${ }^{85}$ Members from both labour parties arrived at the Congress but SRLP delegates successfully passed a motion recognising the SRLP as the sole body "representing the Political Labour Movement in Southern Rhodesia.". Compounding matters, the Southern Rhodesia Trades and Labour Council announced that, due to the split, they might stand their own candidates at the next election. ${ }^{86}$ 
Despite the reduced turnout, ambitions remained high. War was over in Europe and the unexpected landslide victory of the Labour Party in Britain's general election the previous month suggested to some delegates that all now seemed possible. Closer to home, an SALP delegate reported that the party had been able to make "the first big break... in the walls of capitalism" through the passage of the Workmen's Compensation Amendment Act, which increased payments to injured workers. ${ }^{87}$ The Congress confidently asserted that its purpose was to "co-ordinate the efforts of its member organisations in their common aim to achieve, by constitutional means, the establishment in their several states of a Socialist system of Government." 88 There were calls to expand the Congress "to include all Africa, and particularly Kenya," a significant emphasis as Kenya contained the only other sizeable population of white settlers in Britain's African colonies. ${ }^{89}$

Lengthy discussions took place on the financial and monetary arrangements contained in the Bretton Woods Agreement. Opinions ranged from outright hostility to mild scepticism. A compromise was eventually reached that Bretton Woods should be "given a trial" after Colin Legum argued that international institutions could be taken over by the "Socialist countries of the world who would stand up to America." 90 Given how far the white labour movement was from power, the Congress giving approval to Bretton Woods seems a little absurd. Witnessing the proceedings of the Congress was, in the words of Jack Allen, a prominent SRLP member and former Rand miner, like watching "a precocious schoolboy secretly trying on his father's trousers to see what sort of man he would make."91

Yet the significance of these debates lies not only in their grandiose pronouncements. It was decided that a summary of the debates on Bretton Woods should be sent to other labour parties around the British Empire and their own views on the subject 
sought. This was duly carried out and replies were received from labour parties in Britain, Canada and New Zealand.$^{92}$ White labour representatives were making a concerted attempt to insert themselves into international debates as equal participants whose interests and opinions should be considered.

Predictably, another major point of discussion was developing "a common native policy" with another proposal for segregation on a grand scale by removing Africans to rural areas "to develop on their own lines." ${ }^{\text {"3 }}$ There were delegates present who were firm opponents of racial discrimination in the labour movement, including the Mayor of Salisbury, Gladys Maasdorp, who defended the existence of the SRLP's African branch, and the Mayor of Johannesburg, Jessie MacPherson, who played a central role in efforts to remove the colour bar from official SALP policy ${ }^{94}$ MacPherson was close to the Communist Party of South Africa and her attitudes may have been influenced by this association, but Maasdorp was a staunch anti-communist. However, their marginal position in the Congress, and the limited space for these politics in the white labour movement, became clear when SRLP delegates asked Congress to issue an invitation to "Delegates from Organisations and National Bodies which represent Non-European Labour in Southern Africa." "95 "If there is a grain of truth in our talk of representing united Labour," argued Charles Oliver, an SRLP member from Umtali, “ we must admit representatives of non-European workers."96

The motion was not even debated. In an unambivalent indication of the balance of power and opinion at the Congress, it was ruled out of order on the grounds that it would necessitate an amendment to the constitution. That this was a specious argument, but one that was nonetheless accepted, is apparent from the fact that the previous day delegates at the Congress had voted to expel the two MPs from the breakaway party in Southern Rhodesia, even though the constitution stipulated that 
all labour MPs should be represented. Instead, a sub-committee was established to draft a new constitution, to be discussed at the next Congress. ${ }^{97}$ This constitution never saw the light of day.

Dissension and decline in the white labour movement

The fourth Congress scheduled for August 1946 in Salisbury never took place as the organisation established to organise it disintegrated. Importantly, the Congress did not fail because its politics were repudiated by the international labour movement. In fact, some white labour organisations from the region proved surprisingly effective at independently representing themselves, and were acknowledged as part of the international labour movement. The best, and most extraordinary, example took place at the World Federation of Trade Unions conference in London in February 1945 where a white miner from Northern Rhodesia's Copperbelt, Brian Goodwin, attending the conference in his capacity as president of a whites-only union, was elected to the organisation's executive as the representative for Africa. Astonishingly, Goodwin's candidacy was supported by the West African trade unions present at the conference, who also elected Isaac Wallace-Johnson, a trade unionist from Sierra Leone only recently released from internment, as his alternate. ${ }^{98}$

Goodwin's opponent for the position was SATLC General Secretary William de Vries, who was incredulous to find that although the SATLC "had affiliated to it several Native and Coloured workers' organisations," West African delegates argued "that the South Africans could not speak on behalf of the thirty million Blacks" and thus supported Goodwin, who was himself originally from South Africa. The vote was close though and the SATLC was endorsed "as being the most representative group in Africa" by many delegates, including the British Trade Union Congress. ${ }^{99}$ However, protestations 
from de Vries that the SATLC was a multi-racial body must be seen in the context of preparations for the World Federation of Trade Unions conference when the Council on Non-European Trade Unions approached the SATLC to ask for assistance in securing representation at the conference. Even though the Council on Non-European Trade Unions claimed to represent 119 unions with a combined membership of 158,000 , the SATLC rejected their approach on the grounds there was "one national trade union" and this was the SATLC. Any assistance for African unions would be provided by them. ${ }^{100}$ The white labour movement had to occupy centre stage.

The white labour movement was, for the most part, still recognised as the legitimate representatives of the working-class, and white trade unionists continued to represent the region at major international conferences. For instance, in July 1946, around the time the fourth Southern Africa Labour Congress was due to be held, three white trade unionists represented South Africa at meeting of the International Labour Organisation in Montreal, two of whom had previously been delegates at the Congress. ${ }^{101}$ Earlier that year, in January 1946, Canada's Co-operative Commonwealth Federation had suggested that another Dominion Labour Conference be held in Canada during 1946 and invited the NRLP, pledging that delegations from all British colonies would be sought. ${ }^{102}$ Although this fulfilled a longstanding demand of the Southern Africa Labour Congress, that same month the standing committee of the Congress met for what turned out to be the final time. ${ }^{103}$

While the position could be maintained internationally, it could not be sustained domestically. The proposed fourth Congress never took place as many of the component organisations were either embroiled in bitter internal struggles or had effectively collapsed. Infighting was primarily related to a struggle over who exactly the organisations represented: whites only or a wider constituency of African and Indian 
workers. Most leaders of the white labour movement were simply not prepared to accept non-white workers as members of the working class, a class in which they would then be a small minority. The impact of this on the functioning of the Congress can be seen by examining what happened to the individuals elected to the Congress executive in August 1945: Walter Madeley as chairman, Gladys Maasdorp as vicechair, Colin Henderson as secretary and Colin Legum as treasurer. ${ }^{104}$

In 1946, the South African government - the SALP having resigned from the coalition government in October 1945 - introduced the Asiatic Land Tenure and Indian Representation Bill. The Bill tightened restrictions on land ownership by Indians in South Africa but offered a limited franchise for Indians at the national and provincial levels as a kind of recompense. Although the SALP endorsed residential segregation, the party was divided over the extension of the franchise. ${ }^{105}$ The party's leadership endorsed the Bill but Madeley and M.J. van der Berg voted against it in Parliament, precipitating an internal crisis. Madeley resigned from the party while van der Berg defected to the National Party. In a resignation letter leaked to the press, Madeley expressed amazement that leading party members "are blind to the danger to the white race... [of] Indian franchise penetration." ${ }^{106} \mathrm{He}$ was, he declared, "a white man before he was a socialist." ${ }^{107}$ For the same reason, Henry Pereira, who had been appointed to draft a new constitution for the Congress along with Maasdorp and Henderson, resigned from his party positions shortly afterwards in protest. ${ }^{108}$ Days later, Henderson was suspended from the party and subsequently resigned. ${ }^{109}$

In Southern Rhodesia, the organisation Maasdorp represented collapsed during 1946 and its rapidly dwindling membership did not have the capacity to organise anything like the Southern Africa Labour Congress. The split in the white labour movement in the colony had proved irresolvable as reunification talks foundered over the issue of 
African membership. Both parties, which otherwise had virtually identical policies, put up candidates in the April 1946 general election. Predictably, both fared dismally and they were eclipsed by the newly founded Liberal Party as the main opposition force in white politics. The SRLP faired particularly poorly, winning just $5.6 \%$ of the vote and electing only two MPs, both of whom defected to other parties. ${ }^{110}$

In Northern Rhodesia, the NRLP had ceased to function during 1945. Prominent NRMWU members nursed an intense dislike of party leader Roy Welensky, suspecting, correctly, that Welensky had connived in the arrest and deportation of the union's general secretary, Frank Maybank, in 1942. In mid-1944, the party's vicepresident, Martinus Visagie, was ousted from his position as NRMWU General Secretary and then removed from the union and white mineworkers withdrew from NRLP branches on the Copperbelt. ${ }^{111}$ The result was a dismal showing for the party in the September 1944 elections. Only two candidates were elected and, embarrassingly, NRMWU president Brian Goodwin stood as an independent labour candidate on the Copperbelt and defeated the NRLP candidate. ${ }^{112}$ Moreover, by the proposed date of the fourth Congress the Copperbelt's white mineworkers were embroiled in yet another trial of strength with the mining companies as wildcat strikes in July 1946 resulted in most of the union's membership being sacked. ${ }^{113}$

Conflicts at a national level fatally undermined efforts to establish a permanent organisation for the white labour movement across the region. Visions of a post-war world in which the white labour movement would exercise considerable power and implement a racialized social democracy dissipated. National and imperial political developments did strengthen white domination over the region in the immediate postwar period but the Southern Africa Labour Congress expressed a different kind of 
white supremacy: one that was outward-facing, supported by transnational links, and with a legitimate place in the international labour movement and the post-war world.

The commitment of white labour representatives to what they understood as socialism was not superficial, a radical burnish to what was otherwise unreconstructed white supremacy. Most were aware that the world was changing, and welcomed this change, as they saw a central role for themselves and their movement in the post-war world. The labour movement would come to power in the aftermath of the war and they were the labour movement. Delegates at the Congresses saw themselves as part of an international movement, alongside white workers in Britain, Canada, Australia, and New Zealand. All this was predicated on a racialized and gendered understanding of class in which worker meant white male worker participating in a labour movement ideally composed of "men of action, men who will hit and hit hard, and damn the consequences." 114

Identification with international labour was, in part, reciprocated and the white labour movement was acknowledged as the legitimate representatives of the working-class in the region. White labour representatives were confident that disagreements - mainly criticisms emanating from the British Labour Party whose support for African interests was regarded as somewhat mystifying - could be resolved within the movement. What was important, then, was to improve these transnational links and to repackage conceptions of white domination in a historical moment when ideas about race and empire were changing. Although delegates at the Congresses did not have homogenous politics, and some were principled and dedicated opponents of racial discrimination in the labour movement, dissent from the politics of white labourism was limited. 
The Southern Africa Labour Congress brought together the leadership of the white trade unions and labour parties but there was little engagement from the members of these organisations. Leaders of the white trade unions and labour parties were out of step with the class they claimed to represent. The victory of the National Party in 1948 was anathema to English-speaking trade unionists yet a large portion of the white working-class clearly voted for the party. Political developments emanating from outside the white labour movement protected the position of white workers in industry and solidified white domination. In South Africa, this was the onset of apartheid, in Northern and Southern Rhodesia this was the creation of the Central African Federation in 1953, fulfilling the aim long sought by white settlers. The appointment of Roy Welensky, who had disavowed his socialist politics, as Federal Prime Minister in 1956, illustrates that the ends sought by the Congress were achieved by other means. The politics of the white labour movement were not the post-war future, they were the past.

\footnotetext{
${ }^{1}$ I am grateful for the helpful comments and suggestions provided by the editorial board of the journal, particularly Barbara Weinstein, and two anonymous reviewers.

2 It is not the intention to survey this vast literature here. For a recent overview of the South African literature, see Bill Freund, "Labour Studies and Labour History in South Africa: Perspectives from the Apartheid Era and After," International Review of Social History 58 (2013): 493-519. For Zimbabwe, see major edited collections by Brian Raftopoulos and lan Phimister, eds., Keep on knocking: A history of the labour movement in Zimbabwe, 1900-1997 (Harare, 1997) and Brian Raftopoulos and Lloyd Sachikonye, eds., Striking back: The labour movement and the post-colonial state in Zimbabwe 19802000 (Harare, 2001). The literature on Zambia is smaller though follows the same national parameters. Jane Parpart, Labor and Capital on the African Copperbelt (Philadelphia, 1983), Henry Meebelo, African proletarians and colonial capitalism: The origins, growth, and struggles of the Zambian labour movement to 1964 (Lusaka, 1986) and Miles Larmer, Mineworkers in Zambia: Labour and Political Change in Post-Colonial Africa, (London, 2007).

${ }^{3}$ Philip Bonner, Jonathan Hyslop and Lucien van der Walt, "Rethinking Worlds of Labour: Southern African Labour History in International Context," African Studies 66 (2007): 150. Emphasis in original. ${ }^{4}$ Keith Breckenridge, Biometric State: The Global Politics of Identification and Surveillance in South Africa, 1850 to the Present (Cambridge, 2014): x.
} 
${ }^{5}$ Lucien van der Walt, "The First Globalisation and Transnational Labour Activism in Southern Africa: White Labourism, the IWW, and the ICU, 1904-1934," African Studies 66 (2007): 223.

6 Jonathan Hyslop, "The Imperial Working Class Makes Itself 'White': White Labourism in Britain, Australia, and South Africa Before the First World War," Journal of Historical Sociology 12 (1999): 398421, Jonathan Hyslop, "Scottish Labour, Race, and Southern African Empire c.1880-1922: A Reply to Kenefick," International Review of Social History 22 (2010): 63-81.

${ }^{7}$ For insights into how the language of class is used in contemporary political debates, see Jamelle Bouie, "Fake Working Class," Slate, 18 April 2017. Available at:

http://www.slate.com/articles/news and politics/politics/2017/04/the response to the retail apocaly pse shows which workers count in trump.html [Accessed 2 May 2017] and Christina Cauterucci, "When People Talk About "Working-Class" Voters, They Only Mean White, U.S.-Born Men," Slate, 6 April 2017. Available at:

http://www.slate.com/blogs/xx factor/2017/04/06/calls for democrats to focus on working class v oters mean only white u s.html [Accessed 2 May 2017].

8 David Yudelman, The Emergence of Modern South Africa: State, capital, and the incorporation of organized labour on the South African gold fields, 1902-1939 (Cape Town, 1984), 235. Ian Phimister, An economic and social history of Zimbabwe 1890-1948: Capital accumulation and class struggle (London, 1987): 92-3, 189-91.

9 Dan O'Meara, "Analysing Afrikaner Nationalism: The 'Christian-National' Assault on White Trade Unionism in South Africa, 1934-1948," African Affairs 77 (1978): 48.

${ }^{10}$ South African Trades and Labour Council, Report of the Fifteenth Annual Conference (Johannesburg, 1945), 9. Harold Simons and Ray Simons, Class and Colour in South Africa, 1850-1950 (Harmondsworth, 1969), 526.

11 "Conferences Endorses United Labour Policy," Forward, 10 April 1942.

12 "Sign of the Times," Labour-Arbeiders Bulletin, January 1943.

13 SATLC NEC Minutes, 11 September 1945, AH646, Da2.15, Records of the Trade Union Council of South Africa, Historical Papers Archive, University of the Witwatersrand, Johannesburg, South Africa (hereafter cited as TUCSA).

14 Ian Phimister, "White miners in historical perspective: Southern Rhodesia, 1890-1953" Journal of Southern African Studies, 3 (1977): 197.

15 "The First Milestone," The Granite Review, October 1940. I am grateful to Nicola Ginsburgh for sharing her copies of this publication with me.

${ }^{16}$ William Moore to Secretary, SATLC, 15 February 1943, AH 646, Dc12.7, TUCSA.

17 Stanlake Samkange, "A History of the Rhodesia Labour Party: 1920-1948," (BA diss., Harvard University, 1980, 47.

18 J.W. Davidson, The Northern Rhodesian Legislative Council (London, 1948), 43.

19 Duncan Money, "The World of European Labour on the Northern Rhodesian Copperbelt," International Review of Social History 60 (2015): 234-45.

20 In August 1942, several trade union leaders were arrested, two interned and Katanga's mining towns were placed under military rule. 
${ }^{21}$ Peter Alexander, Workers, War \& the Origins of Apartheid: Labour \& politics in South Africa, 193948 (Oxford, 1999), 23.

22 Larry Butler, Copper Empire: Mining and the colonial state in Northern Rhodesia, c. 1930-64 (Basingstoke, 2007), 88.

${ }^{23}$ M.C. Steele, "White Working-Class Disunity: The Southern Rhodesia Labour Party," Rhodesian History 1 (1970): 59-60.

24 Terence Ranger, Bulawayo Burning: The Social History of a Southern African City, 1893-1960 (Harare, 2010), 51.

25 Jon Lewis, Industrialisation and trade union organisation in South Africa, 1924-55: The rise and fall of the South African Trades and Labour Council (Cambridge, 1984), 160.

26 Steele, "Southern Rhodesia Labour Party," 60.

27 "The Colour Bar," Labour-Arbeiders Bulletin, November 1943.

${ }^{28}$ Baruch Hirson, Yours for the Union: Class and Community Struggles in South Africa (London, 1989), 100.

29 Alexander, Origins of Apartheid, 56-7.

30 Meebelo, African Proletarians, 110-4, John Higginson, A Working Class in the Making: Belgian Colonial Labor Policy, Private Enterprise, and the African Mineworkers, 1907-1951 (Madison, 1989), 173-82.

${ }^{31}$ Colin Henderson to Roy Welensky, 25 September 1942, 505/10, Welensky Papers, Bodleian Library, Oxford, UK (hereafter cited as Welensky Papers).

32 Neil Roos, Ordinary Springboks: White Servicemen and Social Justice in South Africa, 1939-1961 (Aldershot, 2005), 36.

${ }^{33}$ Simons and Ray, Class and Colour, 540.

${ }^{34}$ Saul Dubow, "Introduction: South Africa's 1940s," in South Africa's 1940s: Worlds of Possibilities, ed. Saul Dubow and Alan Jeeves (Cape Town, 2005), 2.

35 Tommy Grey to Roy Welensky, 30 May 1941, 700/1, Welensky Papers. Northern Rhodesia Chamber of Mines, Yearbook 1956 (Kitwe, 1957), 68.

${ }^{36}$ Nancy Clark, "Gendering Production in Wartime South Africa," American Historical Review 106 (2001): 1189. Fourth Report on the Census of Industrial Production 1938-1944 (Salisbury, 1946), 9, 22. Report on the Census of Population of Northern Rhodesia held on 15th October, 1946 (Lusaka, 1949), $14,33,35$. The percentage for Southern Rhodesia is an estimate as employment figures in the Census of Industrial Production are incomplete. I am grateful to Victor Gwande and Lazlo Passemiers for directing my attention to these figures. Figures before 1946 are not available for Northern Rhodesia.

${ }^{37}$ Clark, "Gendering Production," 1205-6.

38 Philip Murphy, "'Government by Blackmail': The Origins of the Central African Federation Reconsidered," in The British Empire in the 1950s: Retreat or Revival?, ed. Martin Lynn (Basingstoke, 2005), 53-76.

${ }^{39}$ Labour Party, The Colonies: The Labour Party's post-war policy for the African and Pacific colonies (London, 1943). 
${ }^{40}$ Elaine Katz, A Trade Union Aristocracy: A history of white workers in the Transvaal and the General Strike of 1913 (Johannesburg, 1976), 13.

41 "Arrest of Trade Union Leaders Results in Strike," Forward, 21 August 1942. "Jadotville Trouble, Belgian Congo," Granite Review, October 1942. Both these articles are based on correspondence from NRMWU members.

${ }^{42}$ A 1939 survey of white workers in urban areas in South Africa found that Afrikaners constituted 82\% of unskilled labourers but only $8 \%$ of fitters. Lewis, Industrialisation and Trade Union Organisation, 69. 43 O'Meara, "White Trade Unionism," 64, 70.

44 Lewis, Industrialisation and Trade Union Organisation, 77.

${ }^{45}$ Wessel Visser, "Politics Under Conditions of War: The Effect of the War Measures Act on Political Struggles Within the South African Mine Workers' Union, 1939-47," Scientia Militaria 44 (2016): 211 14.

46 "Mayfair Candidate," The Mineworker/Die Mynwerker, July 1943.

47 Louise Vincent, "Bread and Honour: White Working Class Women and Afrikaner Nationalism in the 1930s," Journal of Southern African Studies 26 (2000): 63, 72.

${ }^{48}$ Alexander, Origins of Apartheid, 89.

49 Minutes, Southern Africa Labour Conference, 17-18 July 1943, 505/10, Welensky Papers.

50 "South African Labour," The Granite Review, September 1943.

51 "South African Labour Gets Together," Forward, 23 July 1943.

52 Minutes, Southern Africa Labour Conference, 17-18 July 1943, 505/10, Welensky Papers.

53 "Absolute Majority for the Government," Forward, 30 July 1943.

54 Minutes, Southern Africa Labour Conference, 17-18 July 1943, 505/10, Welensky Papers.

55 Ibid.

56 lbid.

57 Josiah Brownell, "Out of Time: Global Settlerism, Nostalgia, and the Selling of the Rhodesian Rebellion Overseas," Journal of Southern African Studies, 43 (2017): 813.

58 Minutes, Southern Africa Labour Conference, 17-18 July 1943, 505/10, Welensky Papers. African mineworkers' in Katanga undertook an array of jobs reserved for whites in the mining industry in Northern Rhodesia, Southern Rhodesia, and South Africa.

59 Ibid.

${ }^{60}$ Constitution Adopted at First Southern Africa Labour Congress, AH646, Dd12.20, TUCSA.

61 "Burnside in Rhodesia," Labour-Arbeiders Bulletin, October 1943.

62 For the complete notes from one of Burnside's speeches, see: NRLP Public meeting at Broken Hill, 505/7, Welensky Papers.

63 "Northern Rhodesia," Labour-Arbeiders Bulletin, Mid-October 1943.

${ }^{64}$ F.M. Shepherd to Foreign Secretary, 8 November 1943, CO 795/123/8, The National Archives. This is a report from the British Consul in Katanga.

${ }^{65}$ Ranger, Bulawayo Burning, 34

${ }^{66}$ Samkange, "Rhodesia Labour Party," 69-70.

67 Steele, "Southern Rhodesia Labour Party," 62. 
68 "Addresses of Delegates," Bulawayo Chronicle, 17 July 1944.

${ }^{69}$ Colin Legum to Roy Welensky, 26 April 1944, 505/10, Welensky Papers.

70 Walter Citrine to William de Vries, 9 June 1943, AH 646, Dc12.7, TUCSA.

Report of First Meeting of Representatives of Trades Union Congress with Trade Union Representatives of Canada and South Africa, 12-16 April 1943, AH 646, Da6.11, TUCSA.

71 "Resolutions at Labour Congress," Bulawayo Chronicle, 17 July 1944.

72 "'Amalgamation of the two Rhodesias the First Step," Bulawayo Chronicle, 17 July 1944.

73 Jonathan Hyslop, "'Segregation has fallen on evil days': Smuts' South Africa, global war, and transnational politics, 1939-46," Journal of Global History 7 (2012): 442, 456.

74 "Resolutions at Labour Congress," Bulawayo Chronicle, 17 July 1944.

75 "The Labour Viewpoint," Bulawayo Chronicle, 15 July 1944.

76 "British Labour Party Policy," Bulawayo Chronicle, 17 July 1944.

77 David Lewis to Colin Legum, 26 July 1944, 505/10, Welensky Papers. Lewis was the Co-operative Commonwealth Federation's National Secretary.

78 Colin Legum to Roy Welensky, 25 August 1944, 505/10, Welensky Papers.

79 "Empire Labour and the Peace Conference Manifesto," The Guardian, 28 September 1944.

${ }^{80}$ Report of Delegates to the Dominion Labour Conference, 12-17 September 1944, AH646, Dd13.2, TUCSA.

${ }^{81}$ Roy Welensky to Charles Henderson, 29 May 1945, 505/10, Welensky Papers.

82 Constituent Bodies and Delegates, 11 August 1945, AH646, Dd12.20, TUCSA.

83 SATLC NEC Minutes, 11 July 1944, AH646, Da2.14, TUCSA.

84 Samkange, "Rhodesia Labour Party," 75.

85 "Statement of Labour Policy Adopted," Granite Review, November 1944.

${ }^{86}$ Minutes of Third Annual Congress, 11-12 August 1945, AH646, Dd12.20, TUCSA.

87 Ibid.

88 Resolutions to be discussed at the Southern Africa Labour Congress, 11-12 August 1945, AH646, Dd12.20, TUCSA.

89 "Labour and the Native," The Star Johannesburg, 11 August 1945.

90 Minutes of Third Annual Congress, 11-12 August 1945, AH646, Dd12.20, TUCSA.

91 "An Old Timer Looks at Johannesburg," Forward, 17 August 1945.

92 Colin Henderson to the British Labour Party, Co-operative Commonwealth Federation of Canada, Australian Labor Party and New Zealand Labour Party, 3 September 1945, 505/10, Welensky Papers. 93 "Labour and the Native," The Star Johannesburg, 11 August 1945.

${ }^{94}$ Bob Hepple, Alex Hepple: South African Socialist (Cape Town, 2011), 38.

${ }_{95}$ Minutes of Third Annual Congress, 11-12 August 1945, AH646, Dd12.20, TUCSA.

96 "Labour and the Native," The Star Johannesburg, 13 August 1945.

97 Minutes of Third Annual Congress, 11-12 August 1945, AH646, Dd12.20, TUCSA.

98 Report of the Committee on Nominations to the General Council, the Executive Committee, Box 10, World Federation of Trade Unions Collection, International Institute of Social History, Amsterdam, Netherlands. 
99 Report on World Trade Union Conference, 25 September-October 1945, AH646 Dc13.7, TUCSA.

100 SATLC NEC Minutes, 14 August 1945, AH646, Da2.15, TUCSA. Nancy Clark and William Worger, South Africa: The rise and fall of apartheid (Harlow, 2003), 38.

101 "International Labour Conference," Forward, 12 July 1946.

102 Roy Welensky to Colin Henderson, 16 January 1946, 505/10, Welensky Papers. "Labour Conference in Canada," The Star Johannesburg, 26 January 1946.

103 Colin Henderson to Roy Welensky, 11 February 1946, 505/10, Welensky Papers.

104 Minutes of Third Annual Congress, 11-12 August 1945, AH646, Dd12.20, TUCSA.

${ }^{105}$ Even progressives within the SALP supported the extension of residential segregation on racial lines.

Colin Legum publicly announced at a Johannesburg City Council in 1944 that "We in the Labour Party stand for residential separation of Europeans and Non-Europeans." "Residential Separation for nonEuropeans," Forward, 15 December 1944

106 "Madeley Resigns from Labour Party," Rand Daily Mail, 25 July 1946.

107 Alexander, Origins of Apartheid, 98.

108 "Madeley's Former Secretary Resigns," Rand Daily Mail, 27 July 1946.

109 "Labour Party Suspends Senator Henderson," Rand Daily Mail, 5 August 1946.

110 Samkange, "Rhodesia Labour Party," 95-6.

111 Roy Welensky to Leo Gottlieb, 21 September 1944, 506/10, Welensky Papers.

112 J.R.T. Wood, The Welensky Papers: A history of the Federation of Rhodesia and Nyasaland (Durban, 1983), 89.

113 "All Copperbelt Mines Close Down," Rhodesia Herald, 16 August 1946.

114 "South African Labour Gets Together," Forward, 23 July 1943. 